\title{
Article \\ Molecular Characterization of Salmonella Detected along the Broiler Production Chain in Trinidad and Tobago
}

\author{
Anisa Sarah Khan ${ }^{1}{ }^{(D}$, Rian Ewald Pierneef ${ }^{2}{ }^{(D}$, Narjol Gonzalez-Escalona ${ }^{3}\left(\mathbb{D}\right.$, Meghan Maguire $^{3}$, Cong Li $^{4}$, \\ Gregory H. Tyson ${ }^{4}$, Sherry Ayers ${ }^{4}$, Karla Georges ${ }^{1} \mathbb{D}$, Woubit Abebe ${ }^{5}$ and Abiodun Adewale Adesiyun ${ }^{1,6, *(\mathbb{D})}$
}

1 School of Veterinary Medicine, Faculty of Medical Sciences, University of the West Indies, St. Augustine 999183, Trinidad and Tobago; anisakhan11@gmail.com (A.S.K.); karla.georges@sta.uwi.edu (K.G.)

2 Agricultural Research Council-Biotechnology Platform, Onderstepoort, 100 Old Soutpan Road, Pretoria 0110, South Africa; pierneefr@arc.agric.za

3 Division of Microbiology, Office of Regulatory Science, Center for Food Safety and Applied Nutrition, Food and Drug Administration, College Park, MD 20740, USA;

narjol.gonzalez-escalona@fda.hhs.gov (N.G.-E.); meghan.maguirethon@fda.hhs.gov (M.M.)

4 Division of Animal and Food Microbiology, Office of Research, Center for Veterinary Medicine, U.S. Food and Drug Administration, Laurel, MD 20708, USA; cong.li@fda.hhs.gov (C.L.); gregory.tyson@fda.hhs.gov (G.H.T.); sherry.ayers@fda.hhs.gov (S.A.)

5 Department of Pathobiology, College of Veterinary Medicine, Tuskegee University, 201 Frederick D Patterson Dr, Tuskegee, AL 36088, USA; wabdela@tuskegee.edu

6 Department of Production Animal Studies, Faculty of Veterinary Science, Onderstepoort, University of Pretoria, Private Bag X04, Pretoria 0110, South Africa

* Correspondence: abiodun.adesiyun@sta.uwi.edu

\section{check for} updates

Citation: Khan, A.S.; Pierneef, R.E.; Gonzalez-Escalona, N.; Maguire, M.; Li, C.; Tyson, G.H.; Ayers, S.; Georges, K.; Abebe, W.; Adesiyun, A.A. Molecular Characterization of Salmonella Detected along the Broiler Production Chain in Trinidad and Tobago. Microorganisms 2022, 10, 570. https://doi.org/10.3390/ microorganisms 10030570

Academic Editor: Lisa Gorski

Received: 10 February 2022

Accepted: 4 March 2022

Published: 6 March 2022

Publisher's Note: MDPI stays neutral with regard to jurisdictional claims in published maps and institutional affiliations.

Copyright: (C) 2022 by the authors. Licensee MDPI, Basel, Switzerland. This article is an open access article distributed under the terms and conditions of the Creative Commons Attribution (CC BY) license (https:// creativecommons.org/licenses/by/ $4.0 /)$.

\begin{abstract}
This cross-sectional study determined the serovars, antimicrobial resistance genes, and virulence factors of Salmonella isolated from hatcheries, broiler farms, processing plants, and retail outlets in Trinidad and Tobago. Salmonella in silico serotyping detected 23 different serovars where Kentucky 20.5\% (30/146), Javiana 19.2\% (28/146), Infantis 13.7\% (20/146), and Albany 8.9\% (13/146) were the predominant serovars. There was a $76.0 \%(111 / 146)$ agreement between serotyping results using traditional conventional methods and whole-genome sequencing (WGS) in in silico analysis. In silico identification of antimicrobial resistance genes conferring resistance to aminoglycosides, cephalosporins, peptides, sulfonamides, and antiseptics were detected. Multidrug resistance (MDR) was detected in $6.8 \%(10 / 146)$ of the isolates of which $100 \%$ originated from broiler farms. Overall, virulence factors associated with secretion systems and fimbrial adherence determinants accounted for $69.3 \%$ (3091/4463), and 29.2\% (1302/4463) counts, respectively. Ten of 20 isolates of serovar Infantis $(50.0 \%)$ showed MDR and contained the $b l a_{C T X-M-65}$ gene. This is the first molecular characterization of Salmonella isolates detected along the entire broiler production continuum in the Caribbean region using WGS. The availability of these genomes will help future source tracking during epidemiological investigations associated with Salmonella foodborne outbreaks in the region and worldwide.
\end{abstract}

Keywords: broiler production chain; Salmonella; molecular characterization; whole-genome sequencing; virulence genes; antimicrobial resistance genes; blaCTX-M-65; Trinidad and Tobago

\section{Introduction}

Since the 1950s, Salmonella has been highlighted as an economically important zoonotic pathogen by the World Health Organization (WHO) and the Food and Agriculture Organization of the United Nations (FAO) [1]. The ability of Salmonella to cause self-limiting gastroenteritis, coupled with high mortality rates in humans due to invasive infections are causes for public health concerns $[2,3]$. While many animals serve as reservoirs for Salmonella, poultry, and poultry products are one of the primary sources of salmonellosis in humans. Therefore, the possibility of transmission from reservoirs to other animals and 
humans is concerning. This is compounded by antimicrobial-resistant Salmonella strains within the environment, necessitating surveillance and control measures among suspected reservoirs such as chickens. In addition, $S$. Typhimurium and $S$. Enteritidis are of public health significance due to their ability to cause disease in humans and animals in developed and developing countries. However, variations in Salmonella serovar distribution have been reported in different countries and are said to be a function of geographic location [4,5].

The use of antimicrobial agents in food-producing animals has been implicated in developing multidrug-resistant (MDR) microorganisms and spreading them through the food chain $[6,7]$. Of importance to human health, some cephalosporins ( $\beta$-lactams), quinolones, and aminoglycosides have been classified by the World Health Organization (WHO) as critically important agents since they are used in the treatment of extra-intestinal salmonellosis [8]. The use of ciprofloxacin and ceftiofur as the established therapy protocol for human salmonellosis could be jeopardized as genetic mechanisms promoting MDR isolates have been reported [9]. $\beta$-lactamases constitute the primary mechanism of cephalosporin resistance via enzymatic modification, where different genes are implicated. The extendedspectrum $\beta$-lactamases (ES $\beta \mathrm{L}$ ) include certain alleles of $b l a_{\mathrm{TEM}}$, and all alleles of $b l a_{\mathrm{CTX}-\mathrm{M}}$ and $b a_{S H V}$ genes. Extended-spectrum cephalosporins can also be hydrolyzed by the AmpC $\beta$-lactamases, of which bla $\mathrm{CMY}$ is the most common of particular importance. Quinolone resistance was initially known to develop through chromosomal mutations [10]. However, the recent emergence of plasmid-mediated quinolone resistance (PMQR) mechanisms has been reported. These include $q n r$ genes: $q n r A, q n r B, q n r S, q n r C$, and $q n r D$, that encode pentapeptide repeat proteins that bind to and protect DNA topoisomerase IV from inhibition by quinolones, the aac $\left(6^{\prime}\right)$-Ib-cr (modified acetyltransferase) and qepA (efflux pump) genes, respectively $[11,12]$. Plasmids are traditionally known to carry antimicrobial-resistant genes and several virulence-associated traits; however, other resistance mechanisms have been reported in Salmonella elsewhere [13,14]. Increasing trends of resistance to quinolones and 3rd generation cephalosporins such as ciprofloxacin and ceftiofur in clinical isolates have led to the introduction of carbapenems and colistin as critical antibiotics of last resort in human salmonellosis [8]. However, the use of colistin to treat both humans and animals has resulted in the emergence of mobilized colistin resistance $(\mathrm{mcr})$ genes [15,16]. To date, nine variants of $\mathrm{mcr}$ genes have been detected in Salmonella isolated from humans and animals [16-18].

Similar genetic determinants conferring resistance to aminoglycosides, tetracyclines, beta-lactams, and fluoroquinolones have been detected in Salmonella strains isolated from livestock and humans, concluding that food and environmental contamination from livestock are carriers of antimicrobial-resistant (AMR) Salmonella and are sources of infection to humans [19-21]. Thus, it is critical to investigate the resistance profiles and phenotypes they exhibit, and the mutations responsible for resistance using molecular analysis methods.

Therefore, the objectives of this study were to determine the genotypic profiles (serovar, antimicrobial resistance, and virulence factors) of Salmonella isolated from various stages of the broiler production-processing-retailing chain in Trinidad and Tobago.

\section{Materials and Methods}

\subsection{Sample Selection}

A total of 146 isolates of Salmonella used in this study originated from prior studies conducted at hatcheries and broiler farms [22], broiler processing plants [23], and retail outlets (pluck shops and supermarkets) [24,25]. The type of samples collected from the various studies are as follows, hatcheries: broken eggshells, eggs in the hatcher, eggs in the incubator, hatcher environmental swabs, hatcher fluff, and stillborn chicks; broiler farms: boot swabs, cloacal swabs, litter drag swabs, feed, and water samples-in-house supply and storage tank; processing plants: chilled chicken parts, chilled whole carcasses, neck skins, pre-evisceration carcasses, and post-evisceration carcasses; retail outlets: chicken carcasses. From a total of 207 duplicate isolates (from different enrichment and selective media) of Salmonella, which represented 23 serovars from the aforementioned sources, the selected 
146 isolates were representatives of the serovars recovered from all Salmonella-positive samples. Briefly, samples were processed to isolate Salmonella using two enrichments broths, Rappaport-Vassiliadis Soya (RVS) and tetrathionate (TT) (Oxoid, Hampshire, England), and two selective agar, brilliant green agar (BGA) and xylose lysine tergitol 4 (XLT-4) selective media (Oxoid, Hampshire, England) [26]. Suspected Salmonella colonies (pink isolated colonies on BGA, red colonies with black centers on XLT-4) were subjected to biochemical tests for identification of Salmonella spp. using standard methods [27]. Isolates of Salmonella recovered from the four combinations of media (RVS/BGA, RVS/XLT-4, TT/BGA, and TT/XLT-4) were initially screened using the conventional slide agglutination test. Thereafter, 146 non-duplicate isolates of Salmonella, randomly selected to represent the serovars and positive samples were subjected to whole-genome sequencing. The following is a summary of the number of isolates included from earlier studies: hatcheries $(n=10)$, farms $(n=20)$, processing plant $(n=61)$, and retail outlets $(n=55)$. Five additional human clinical isolates of Salmonella obtained from the Caribbean Public Health Agency (CARPHA) were included in our panel of isolates subjected to WGS.

\subsection{DNA Extraction and Sequencing}

DNA was extracted using the Maxwell RSC cultured cells DNA kit with a Maxwell RSC instrument (Promega Corporation, Madison, WI, USA) following the manufacturer's protocols for Gram-negative bacteria with additional RNase treatment. DNA concentrations were measured with a Qubit fluorometer (Life Technologies, Carlsbad, CA, USA), standardized to $0.2 \mathrm{ng} / \mu \mathrm{L}$, and the samples were stored at $4{ }^{\circ} \mathrm{C}$ before library preparation.

Whole-genome sequencing (WGS) of the Salmonella isolates was performed by the Public Health Agency of Canada (PHAC) Laboratory and Food and Drug Administration (FDA): Center for Food Safety and Applied Nutrition genomics laboratory (FDA-CFSAN) and Center for Veterinary Medicine (FDA-CVM), Maryland, USA. The WGS data was generated on an Illumina MiSeq using $2 \times 250 \mathrm{bp}$ and $2 \times 300 \mathrm{bp}$ paired-end chemistry (Illumina Inc., San Diego, CA, USA) according to the manufacturer's instructions, at 50$150 X$ coverage. According to the manufacturer's instructions, the libraries were constructed using $100 \mathrm{ng}$ of genomic DNA using the Illumina DNA Prep (M) Tagmentation kit (Illumina Inc., San Diego, CA, USA) and the Nextera XT kit (Illumina Inc., San Diego, CA, USA).

\subsection{Genomic Data Analysis and In Silico Determination of Genetic Elements}

Quality control including adapter removal of the raw data was conducted using BBDuk (v.37.90; https://jgi.doe.gov/data-and-tools/bbtools/bb-tools-user-guide/bbduk-guide/, accessed on 23 July 2021); sourceforge.net/projects/bbmap/). SPAdes v.3.12.0 [28] was used to create a de novo assembly of each isolate. Only contigs larger than $500 \mathrm{bp}$ were retained for further analysis. Serovar prediction was made using command-line version of SISTR [29] (Version: sistr_cmd v.1.1.1).

Gene finding in each isolate was performed with Prodigal v.2.6.3 [30] (parameters $-c-n)$.

VFDB [31] was used to assign virulence factors. This was carried out with the predicted genes (amino acid format) from Prodigal using NCBI-blast-2.9.0+. Results were filtered for the top hit with $100 \%$ identity and 100\% alignment length.

CARD [32] was used to assign antimicrobial resistance. This was performed with the predicted genes (amino acid format) from Prodigal using NCBI-blast-2.9.0+. Results were filtered for the top hit with $100 \%$ identity and $100 \%$ alignment length.

\subsection{Phenotypic Methods Used for Comparison with WGS}

Conventional serotyping methods using the phase reversal technique described previously $[22,23,25]$ were performed at the Public Health Laboratory, Ministry of Health, St. Michael, Barbados. Antimicrobial resistance determined by the disk diffusion method [22-24] described previously was also used. Data generated from these two methods were compared to the genomic data. 


\subsection{Statistical Analyzes}

$\mathrm{R}$ version 4.0.2 was used for Chi-square analysis and data visualization.

\subsection{Data Deposition}

The draft genome sequence of all S. enterica strains have been deposited at GenBank under the accession listed in Table S1-Metadata of 146 Salmonella isolates detected along the broiler production chain in Trinidad and Tobago.

\section{Results}

\subsection{Serotyping Results}

Overall, the 146 isolates of Salmonella subjected to conventional serotyping methods were classified into 23 serovars and 3 unspecific groups (unknown serotype). In silico analysis of the WGS data generated from these 146 isolates using the SISTR software identified 23 different serovars where Kentucky 20.5\% (30/146), Javiana 19.2\% (28/146), Infantis $13.7 \%(20 / 146)$, and Albany $8.9 \%(13 / 146)$ were the predominant serovars. There was a $76.0 \%(111 / 146)$ agreement in the test results of both methods. Isolates classified as $S$. Albany $(n=2)$, Gaminara $(n=2)$, Oranienburg $(n=1)$, and Soerenga $(n=1)$ by SISTR were all classified as $S$. Infantis $(n=6)$ using the traditional method. Three $S$. Warragul isolates detected using the conventional method were classified as $S$. Caracas on SISTR analysis. The distribution of serovars of Salmonella isolates from various sources is shown in Table 1.

Table 1. The distribution of serovars of Salmonella isolates from various sources based on in silico analysis.

\begin{tabular}{|c|c|c|c|c|c|}
\hline \multirow[b]{2}{*}{ Serovars } & \multicolumn{5}{|c|}{ No. of Strains of Salmonella Detected from the Following: } \\
\hline & Hatchery & Farm & Processing Plant & Pluck Shop $^{a}$ & Supermarket $^{\mathrm{a}}$ \\
\hline Aberdeen & 0 & 0 & 1 & 1 & 0 \\
\hline Alachua & 0 & 0 & 1 & 0 & 0 \\
\hline Albany & 0 & 4 & 8 & 1 & 0 \\
\hline Anatomy & 0 & 0 & 5 & 0 & 0 \\
\hline Caracas & 0 & 0 & 0 & 3 & 0 \\
\hline Chester & 0 & 0 & 0 & 0 & 2 \\
\hline Enteritidis & 0 & 0 & 9 & 0 & 0 \\
\hline Fresno & 1 & 0 & 0 & 0 & 0 \\
\hline Gaminara & 0 & 3 & 0 & 0 & 0 \\
\hline Infantis & 0 & 11 & 9 & 0 & 0 \\
\hline Javiana & 0 & 0 & 10 & 17 & 1 \\
\hline Kentucky & 8 & 0 & 7 & 12 & 3 \\
\hline Liverpool & 0 & 0 & 1 & 0 & 0 \\
\hline Manhattan & 0 & 0 & 0 & 7 & 0 \\
\hline Mbandaka & 0 & 0 & 1 & 0 & 0 \\
\hline Molade & 0 & 0 & 0 & 0 & 1 \\
\hline Montevideo & 0 & 0 & 0 & 2 & 1 \\
\hline Oranienburg & 0 & 1 & 0 & 0 & 0 \\
\hline Schwarzengrund & 0 & 0 & 7 & 1 & 0 \\
\hline Senftenberg & 1 & 0 & 0 & 2 & 1 \\
\hline Soerenga & 0 & 1 & 0 & 0 & 0 \\
\hline Virchow & 0 & 0 & 1 & 0 & 0 \\
\hline Weltevreden & 0 & 0 & 1 & 0 & 0 \\
\hline Sub-total & 10 & 20 & 61 & 46 & 9 \\
\hline
\end{tabular}

\subsection{Antimicrobial Resistance Profiles}

A total of 71 ARO accessions (Antibiotic Resistance Ontology, as defined by CARD) were detected among 22 isolates. Genes associated with aminoglycoside resistance, i.e., aac(3)-IV (plasmid-encoded), aac ( $\left.6^{\prime}\right)$-Iaa (chromosomal- encoded), aac( $\left.6^{\prime}\right)$ Iy (chromosomalencoded), $a p h\left(3^{\prime}\right)$-Ia (plasmid-encoded), and $a p h(4)-I a$ (plasmid-encoded) (Table 2) were 
found at frequencies ranging from $1.4 \%$ to $7.5 \%$. All our S. Manhattan and S. Aberdeen strains containing the often silent, chromosomal-encoded aac $\left(6^{\prime}\right)$-Iaa and aac $\left(6^{\prime}\right)$ Iy genes, exhibited phenotypic aminoglycoside resistance. Ten (6.8\%) of 146 isolates contained the bla $_{C T X-M-65}$ gene, which confers cephalosporin resistance. This gene was identified in $S$. Infantis isolates only. Genes qacEDelta1 and sul1, responsible for antiseptic and sulfonamide resistance, were each detected at a frequency of $8.2 \%(12 / 146)$. mcr-9, the mobilized and plasmid-mediated colistin resistance gene, was found in only one isolate. Table 3 shows the distribution of AROs among Salmonella isolates from various sources. Isolates from broiler farms accounted for $83.1 \%(59 / 71)$ of AROs where the predominance of aac(3)-IV (9.9\%; 7/71), aph(4)-Ia (9.9\%; 7/71), qacEdelta1 (9.9\%; 7/71), sul1 (9.9\%; 7/71), and bla CTX-M-65 $(9.9 \% ; 7 / 71)$ among cloacal swab isolates $(62.7 \% ; 37 / 59)$ was evident. Salmonella isolated from the water supply at farms $(18.6 \% ; 11 / 59)$ were found to contain $66.7 \%(6 / 9)$ of the AROs found in this study except for $m c r-9.1$, aac $\left(6^{\prime}\right)$-Iaa and $a a c\left(6^{\prime}\right)$-Iy.

Table 2. Antimicrobial class and genes detected in 146 Salmonella isolates were used in this study.

\begin{tabular}{|c|c|c|c|c|c|c|c|}
\hline \multicolumn{8}{|c|}{ Antimicrobial Class and Genes Detected ${ }^{a}$} \\
\hline Pattern & Aminoglycoside & Disinfectant & Cephalosporin & Peptide & Sulphonamide & $\begin{array}{l}\text { Number of } \\
\text { Isolates (\%) }\end{array}$ & Serovar $(n, \%)$ \\
\hline Pattern 1 & $\begin{array}{l}\text { aph(4)-Ia } \\
\operatorname{aac}(3)-I V\end{array}$ & qacEDelta1 & $b l a_{C T X-M-65}$ & - & sul1 & $6(4.2)$ & Infantis $(6,100.0)$ \\
\hline Pattern 2 & $\begin{array}{l}\operatorname{aph}\left(3^{\prime}\right)-I a \\
\operatorname{aph}(4)-I a \\
\operatorname{aac}(3)-I V\end{array}$ & qacEDelta1 & - & - & sul1 & $1(0.7)$ & Infantis $(1,100.0)$ \\
\hline Pattern 3 & $\begin{array}{l}\operatorname{aph}\left(3^{\prime}\right) I a \\
\operatorname{aph}(4)-I a \\
\operatorname{aac}(3)-I V\end{array}$ & qacEDelta1 & $b l a_{\mathrm{CTX}-\mathrm{M}-65}$ & - & sul1 & $4(2.8)$ & Infantis $(4,100.0)$ \\
\hline Pattern 4 & - & qacEDelta1 & - & - & sul1 & $1(0.7)$ & Senftenberg $(1,100.0)$ \\
\hline Pattern 5 & $a a c\left(6^{\prime}\right)-I a a$ & - & - & - & - & $7(4.9)$ & Manhattan $(7,100.0)$ \\
\hline Pattern 6 & $\operatorname{aac}\left(6^{\prime}\right)-I y$ & - & - & - & - & $2(1.4)$ & Aberdeen $(2,100.0)$ \\
\hline Pattern 7 & - & - & - & $m c r-9.1$ & - & $1(0.7)$ & Senftenberg $(1,100.0)$ \\
\hline Total & $20(14.9)$ & $12(9.0)$ & $10(7.5)$ & $1(0.7)$ & $12(9.0)$ & $22(16.1)$ & \\
\hline
\end{tabular}

${ }^{a}$ Of a total of 146 isolates subjected to CARD analyzes, AMR genes were detected in 22 isolates shown, 121 isolates possessing the core gene gols (regulator of a multidrug efflux pump) were not included in the table and three isolates were negative for resistance genes (Liverpool, Mbandaka, and Oranienburg).

Table 3. Frequency of ARO accessions detected in this study.

\begin{tabular}{|c|c|c|c|c|c|c|}
\hline \multirow[b]{2}{*}{ ARO Name ${ }^{a}$} & \multirow[b]{2}{*}{ No. of AROs } & \multirow[b]{2}{*}{ Overall Frequency $(\%)^{b}$} & \multicolumn{4}{|c|}{ Distribution of AROs among the Various Sampling Levels } \\
\hline & & & Hatchery & Farm & Processing Plant & Retail Outlet \\
\hline $\operatorname{aac}(3)-I V$ & 11 & 7.5 & 0 & 11 & 0 & 0 \\
\hline$a a c\left(6^{\prime}\right)-I a a$ & 7 & 4.8 & 0 & 0 & 0 & 7 \\
\hline $\operatorname{aac}\left(6^{\prime}\right)-I y$ & 2 & 1.4 & 0 & 0 & 1 & 1 \\
\hline $\operatorname{aph}\left(3^{\prime}\right)-I a$ & 5 & 3.4 & 0 & 5 & 0 & 0 \\
\hline$a p h(4)-I a$ & 11 & 7.5 & 0 & 11 & 0 & 0 \\
\hline bla $_{C T X-M-65}$ & 10 & 6.8 & 0 & 10 & 0 & 0 \\
\hline$m c r-9.1$ & 1 & 0.7 & 1 & 0 & 0 & 0 \\
\hline qacEDelta1 & 12 & 8.2 & 0 & 11 & 0 & 1 \\
\hline sul1 & 12 & 8.2 & 0 & 11 & 0 & 1 \\
\hline Total & 71 & & 1 & 59 & 1 & 10 \\
\hline
\end{tabular}

a Antibiotic-resistant ontology name in accordance with the Comprehensive Antibiotic Resistance Database (CARD) software. ${ }^{\mathrm{b}} \mathrm{A}$ total of $71 \mathrm{ARO}$ counts were detected in 146 isolates.

Overall, 6.8\% (10/146) MDR (resistance to 3 or more classes of antimicrobial agents, according to CARD classification) isolates were detected, of which $100 \%$ were recovered at broiler farms and belonged to serovar Infantis. 


\subsection{Virulence Profile}

Overall, for the Salmonella strains from the four sources (hatcheries, farms, processing plants, and retail outlets), 4463 different virulence factors belonging to five virulence classes were identified. Genes classified as secretion systems and fimbrial adherence determinant classes accounted for the predominant virulence classes of 69.3\% (3091/4463) and 29.2\% $(1302 / 4463)$ counts, respectively. Magnesium uptake, stress adaptation, and toxin classes accounted for less than $1.3 \%(56 / 4463)$ counts, respectively. Salmonella isolates $(n=10)$ recovered from the hatcheries contained virulence factors belonging to secretion systems $(4.2 \%, 187 / 4463)$ and fimbrial adherence determinants $(2.0 \%, 91 / 4463)$, whereas farm isolates $(n=20)$ were found to contain fimbrial adherence determinants, $4.4 \%(198 / 4463)$, and secretion system, $10.1 \%(451 / 4463)$. Processing plant Salmonella isolates $(n=61)$ contained predominantly factors in the secretion systems, fimbrial adherence determinants, and toxins, accounting for $30.0 \%(1341 / 4463), 12.4 \%(553 / 4463)$, and $0.6 \%(26 / 4463)$ count, respectively. Retail outlet isolates $(n=55)$ contained fimbrial adherence determinants, $10.3 \%$ (460/4463), secretion system, $24.9 \%(1112 / 4463)$, and toxin-related factors, $0.6 \%(27 / 4463)$. The differences in the detection of virulence factors among the sources were statistically significant $(p<0.001)$.

Serovars Kentucky, Javiana, and Infantis contained higher numbers of virulence factors (all related to secretion systems), accounting for 13.0\% (578/4463), 12.1\% (540/4463), and $12.1 \%(517 / 4463)$, respectively, of the virulence factors (Table S2). Therefore, it is pertinent to mention that they were the predominant serovars detected in this study.

$S$. Infantis isolates contained factors associated with secretion systems (TTSS-1 translocated effectors, TTSS-SPI-1-, and TTSS-SPI-2-encoded genes), 12.1\% (540/4463), and factors associated with fimbrial adherence determinants ( $b c f A, D, F, \operatorname{csg} A, B, C, E, F, G$, and lpfB, $E), 4.9 \%(220 / 4463)$. For the isolates of $S$. Javiana, $11.6 \%$ (517/4463), 4.4\% (196/4463), and $0.6 \%(28 / 4463)$ were positive for factors associated with secretion systems, fimbrial adherence determinants $(b c f A, \operatorname{csg} A, C, D, F, G$, and fim $F)$, and toxins ( $c d t B)$, respectively. Only secretion system and fimbrial adherence determinant factors were detected among Kentucky isolates, accounting for 13.0\% (578/4463) and 5.9\% (263/4463), respectively. S. Schwarzengrund, Senftenberg, and Caracas contained predominantly factors associated with secretion systems at frequencies ranging from $1.3 \%$ to $2.8 \%$. Seven serovars (Caracas, Chester, Enteritidis, Gaminara, Javiana, Montevideo, and Schwarzengrund) contained virulence factors related to toxins, where the $c d t B$ was detected in all except serovar Enteritidis, where the $\operatorname{spv} B$ gene was detected.

\subsection{Comparison of Frequency of Detection of Resistance and Virulence Factors in Salmonella Strains}

Comparisons between the possession of virulence factors (VFDB accessions) and AMR genes (ARO accessions) across serovars were performed and detected 10 sources and years (farm-to-fork, hatcheries, processing plants, retail outlets, ' pluck shops', supermarkets, 2016, 2017, 2018, and 2019). Statistically significant positive correlations in Salmonella serovars isolated from farms, retail outlets, and 'pluck shops', as well as those isolated in 2016 and 2019 were detected, respectively $(p<0.05)$ (Figure 1). Negative and non-significant positive correlations are not displayed. 

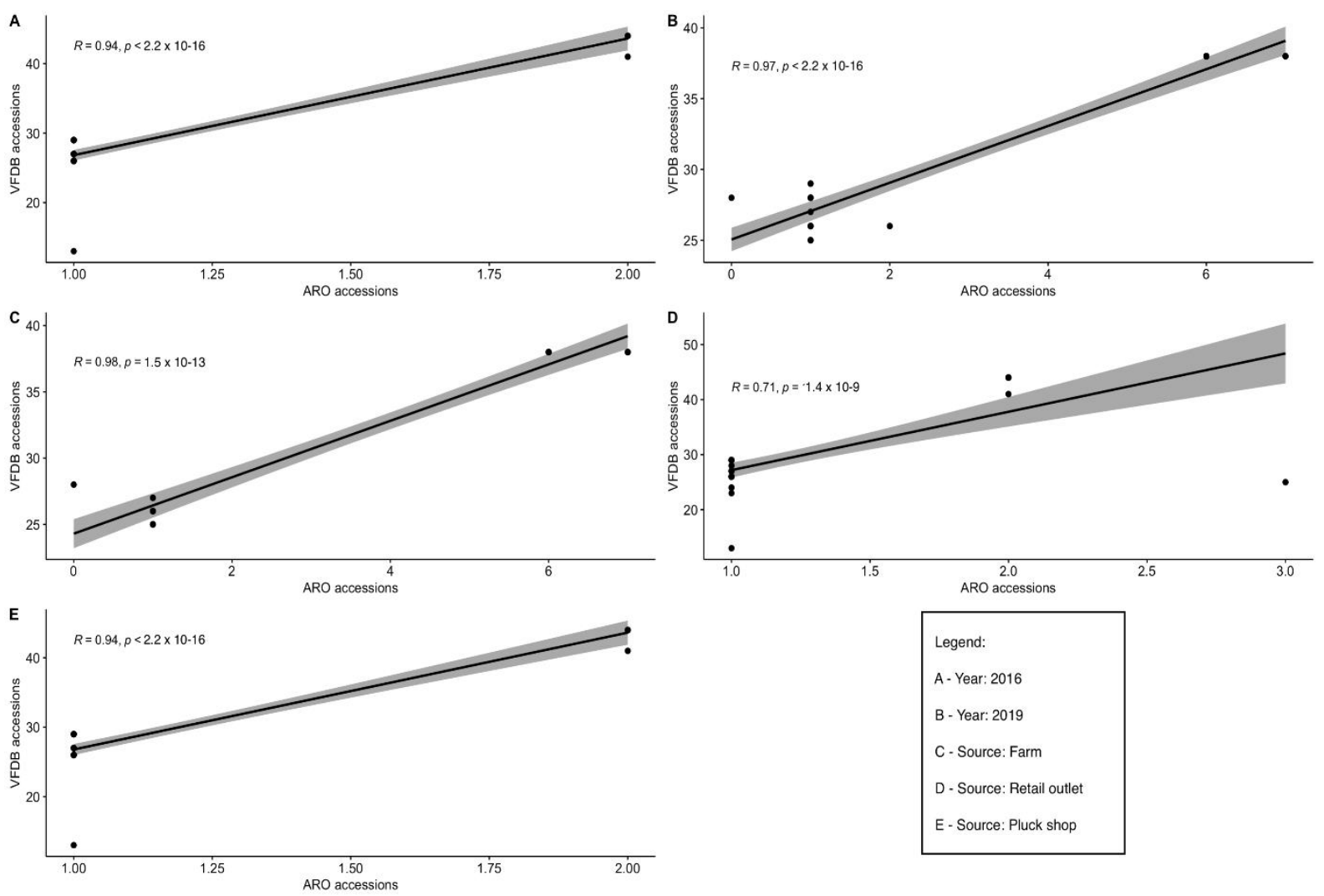

Figure 1. VFDB accessions (virulence) versus ARO accessions (AMR) (A-E).

\subsection{Detection of ESBL Resistance Genes and Virulence Genes in Isolates of S. Infantis}

A comparison of the phenotypic and genotypic resistance patterns in $S$. Infantis isolates is displayed in Table 4 . The bla $a_{C T X-M-65}$ gene was only detected among the $S$. Infantis isolates. Of the 10 isolates of serovar Infantis positive for $b a_{C T X-M-65}$ gene, phenotypically (using the disk diffusion method), two were resistant to two classes of antimicrobial agents, and six were MDR. However, genotypically, all 10 Infantis isolates exhibited MDR. Furthermore, the resistance gene qacEDelta1 responsible for antiseptic resistance was found in all the 10 serovar Infantis isolates. Additionally, virulence factors associated with fimbrial adherence determinants and the secretion system were detected in all the 10 isolates of serovar Infantis.

Table 4. Detection of the bla $a_{C T X-M-65}$ gene, other resistance genes, and virulence genes in $S$. Infantis.

\begin{tabular}{|c|c|c|c|c|c|c|c|c|c|c|}
\hline \multirow[t]{2}{*}{ BioSample } & \multirow[t]{2}{*}{ Isolate No. ${ }^{a}$} & \multicolumn{7}{|c|}{ Phenotypic AMR Using the Disk Diffusion Method ${ }^{b, c, d}$} & \multicolumn{2}{|c|}{ Genotypic Characteristics ${ }^{e}$} \\
\hline & & $\mathbf{P}$ & TE & CE & AM & PH & $\mathbf{S}$ & $\mathbf{F}$ & $\begin{array}{c}\text { Other } \\
\text { Resistance } \\
\text { Genes } \\
\text { Detected }^{\mathrm{f}}\end{array}$ & $\begin{array}{l}\text { Virulence } \\
\text { Factors }\end{array}$ \\
\hline SAMN25867756 & F 17 & S & $\mathrm{R}$ & $\mathrm{R}$ & $\mathrm{R}$ & S & $\mathrm{R}$ & S & $\begin{array}{c}\text { qacEDelta1 } \\
\text { aph(4)-Ia } \\
\operatorname{aac}(3)-I V \\
\text { sul1 }\end{array}$ & $\begin{array}{c}a g f / c s g \\
b c f \\
\text { lpf } \\
\text { TTSS (SPI-1 } \\
\text { encode) } \\
\text { TTSS (SPI-2 } \\
\text { encode) } \\
\text { TTSS-1 } \\
\text { translocated } \\
\text { effectors }\end{array}$ \\
\hline
\end{tabular}


Table 4. Cont.

\begin{tabular}{|c|c|c|c|c|c|c|c|c|c|c|}
\hline \multirow[t]{2}{*}{ BioSample } & \multirow[t]{2}{*}{ Isolate No. ${ }^{a}$} & \multicolumn{7}{|c|}{ Phenotypic AMR Using the Disk Diffusion Method ${ }^{b, c, d}$} & \multicolumn{2}{|c|}{ Genotypic Characteristics ${ }^{e}$} \\
\hline & & $\mathbf{P}$ & TE & $\mathrm{CE}$ & AM & PH & $\mathbf{S}$ & $\mathbf{F}$ & $\begin{array}{c}\text { Other } \\
\text { Resistance } \\
\text { Genes } \\
\text { Detected }^{\mathrm{f}}\end{array}$ & $\begin{array}{l}\text { Virulence } \\
\text { Factors }\end{array}$ \\
\hline SAMN25867757 & F 22 & $\mathrm{~S}$ & $\mathrm{R}$ & $\mathrm{R}$ & $\mathrm{R}$ & S & $\mathrm{R}$ & S & $\begin{array}{c}\text { qacEDelta1 } \\
\text { aph(4)-Ia } \\
\text { aac(3)-IV } \\
\text { sul1 }\end{array}$ & $\begin{array}{c}a g f / c s g \\
b c f \\
\text { lpf } \\
\text { TTSS (SPI-1 } \\
\text { encode) } \\
\text { TTSS (SPI-2 } \\
\text { encode) } \\
\text { TTSS-1 } \\
\text { translocated } \\
\text { effectors }\end{array}$ \\
\hline SAMN14677229 & F 11 & $\mathrm{~S}$ & $\mathrm{R}$ & $\mathrm{R}$ & $\mathrm{R}$ & S & $\mathrm{R}$ & S & $\begin{array}{c}\text { qacEDelta1 } \\
\text { aph(4)-Ia } \\
\text { aac(3)-IV } \\
\text { sul1 }\end{array}$ & $\begin{array}{c}a g f / c s g \\
b c f \\
l p f \\
\text { TTSS (SPI-1 } \\
\text { encode) } \\
\text { TTSS (SPI-2 } \\
\text { encode) } \\
\text { TTSS-1 } \\
\text { translocated } \\
\text { effectors }\end{array}$ \\
\hline SAMN14677211 & F 32 & $S$ & $\mathrm{R}$ & $\mathrm{R}$ & $\mathrm{R}$ & $S$ & $\mathrm{R}$ & $S$ & $\begin{array}{c}\text { aph }\left(3^{\prime}\right)-I a \\
\text { qacEDelta1 } \\
\text { aph(4)-Ia } \\
\text { aac(3)-IV } \\
\text { sul1 }\end{array}$ & $\begin{array}{c}a g f / c s g \\
b c f \\
l p f \\
\text { TTSS (SPI-1 } \\
\text { encode) } \\
\text { TTSS (SPI-2 } \\
\text { encode) } \\
\text { TTSS-1 } \\
\text { translocated } \\
\text { effectors }\end{array}$ \\
\hline SAMN14677232 & F 36 & $S$ & $\mathrm{R}$ & $\mathrm{R}$ & $\mathrm{R}$ & $S$ & $\mathrm{R}$ & $S$ & $\begin{array}{c}\text { aph(3')-Ia } \\
\text { qacEDelta1 } \\
\text { aph(4)-Ia } \\
\text { aac(3)-IV } \\
\text { sul1 }\end{array}$ & $\begin{array}{c}a g f / c s g \\
b c f \\
\text { lpf } \\
\text { TTSS (SPI-1 } \\
\text { encode) } \\
\text { TTSS (SPI-2 } \\
\text { encode) } \\
\text { TTSS-1 } \\
\text { translocated } \\
\text { effectors }\end{array}$ \\
\hline SAMN14677210 & F 2 & $S$ & $S$ & $S$ & $S$ & $S$ & $S$ & $S$ & $\begin{array}{c}\text { qacEDelta1 } \\
\text { aph(4)-Ia } \\
\text { aac(3)-IV } \\
\text { sul1 }\end{array}$ & $\begin{array}{c}a g f / c s g \\
b c f \\
l p f \\
\text { TTSS (SPI-1 } \\
\text { encode) } \\
\text { TTSS (SPI-2 } \\
\text { encode) } \\
\text { TTSS-1 } \\
\text { translocated } \\
\text { effectors }\end{array}$ \\
\hline
\end{tabular}


Table 4. Cont.

\begin{tabular}{|c|c|c|c|c|c|c|c|c|c|c|}
\hline \multirow[t]{2}{*}{ BioSample } & \multirow[t]{2}{*}{ Isolate No. ${ }^{\mathrm{a}}$} & \multicolumn{7}{|c|}{ Phenotypic AMR Using the Disk Diffusion Method b,c,d } & \multicolumn{2}{|c|}{ Genotypic Characteristics ${ }^{\text {e }}$} \\
\hline & & $\mathbf{P}$ & TE & CE & AM & PH & S & $\mathbf{F}$ & $\begin{array}{c}\text { Other } \\
\text { Resistance } \\
\text { Genes } \\
\text { Detected }\end{array}$ & $\begin{array}{l}\text { Virulence } \\
\text { Factors }\end{array}$ \\
\hline SAMN14677203 & F 4 & S & $\mathrm{R}$ & $\mathrm{R}$ & $\mathrm{R}$ & $\mathrm{S}$ & $S$ & $\mathrm{R}$ & $\begin{array}{c}\text { qacEDelta1 } \\
\text { aph(4)-Ia } \\
\text { aac(3)-IV } \\
\text { sul1 }\end{array}$ & $\begin{array}{c}a g f / c s g \\
b c f \\
l p f \\
\text { TTSS (SPI-1 } \\
\text { encode) } \\
\text { TTSS (SPI-2 } \\
\text { encode) } \\
\text { TTSS-1 } \\
\text { translocated } \\
\text { effectors }\end{array}$ \\
\hline SAMN14677209 & UWI-F30 & S & S & S & S & S & S & S & $\begin{array}{c}\text { aph(3')-Ia } \\
\text { qacEDelta1 } \\
\text { aph(4)-Ia } \\
\text { aac(3)-IV } \\
\text { sul1 }\end{array}$ & $\begin{array}{c}a g f / c s g \\
b c f \\
l p f \\
\text { TTSS (SPI-1 } \\
\text { encode) } \\
\text { TTSS (SPI-2 } \\
\text { encode) } \\
\text { TTSS-1 } \\
\text { translocated } \\
\text { effectors }\end{array}$ \\
\hline SAMN14677207 & UWI-F9 & $S$ & $\mathrm{R}$ & S & $\mathrm{R}$ & $S$ & $S$ & S & $\begin{array}{c}\text { qacEDelta1 } \\
\operatorname{aph}(4)-I a \\
\operatorname{aac}(3)-I V \\
\text { sul1 }\end{array}$ & $\begin{array}{c}a g f / c s g \\
b c f \\
l p f \\
\text { TTSS (SPI-1 } \\
\text { encode) } \\
\text { TTSS (SPI-2 } \\
\text { encode) } \\
\text { TTSS-1 } \\
\text { translocated } \\
\text { effectors }\end{array}$ \\
\hline SAMN14677208 & UWI-F31 & $S$ & $\mathrm{R}$ & S & $\mathrm{R}$ & S & $S$ & $S$ & $\begin{array}{c}\text { aph }\left(3^{\prime}\right)-I a \\
\text { qacEDelta1 } \\
\text { aph(4)-Ia } \\
\text { aac(3)-IV } \\
\text { sul1 }\end{array}$ & $\begin{array}{c}a g f / c s g \\
b c f \\
\text { lpf } \\
\text { TTSS (SPI-1 } \\
\text { encode) } \\
\text { TTSS (SPI-2 } \\
\text { encode) } \\
\text { TTSS-1 } \\
\text { translocated } \\
\text { effectors }\end{array}$ \\
\hline
\end{tabular}

${ }^{a}$ All 10 isolates were obtained from broiler farms comprising 7 (70\%) cloacal swabs, 2 (20\%) water supply (UWIF30 and UWI-F9), and 1 drag swab of litter (UWI-F31) from where blaCTX-M-65, the only ES $\beta L$-resistance gene was detected. ${ }^{\mathrm{b}} \mathrm{P}$, penam (amoxicillin-clavulanic acid, $30 \mu \mathrm{g}$ ); TE, tetracycline (doxycycline, $30 \mu \mathrm{g}$ ); $\mathrm{CE}$, cephalosporin (ceftriaxone, $30 \mu \mathrm{g}$ ); AM, aminoglycoside (gentamicin, $10 \mu \mathrm{g}$, and kanamycin, $30 \mu \mathrm{g}$ ); PH, phenicol (chloramphenicol, $30 \mu \mathrm{g}$ ); S, sulphonamide (sulfamethoxazole-trimethoprim, 23.75 and $1.25 \mu \mathrm{g}$ ); F, fluoroquinolone (ciprofloxacin, $5 \mu \mathrm{g}$ ). ${ }^{\mathrm{c}} \mathrm{A}$ total of 146 (151 with controls) isolates of Salmonella were tested for AMR by the disk diffusion method, resistance genes, and virulence genes by WGS where $6.6 \%(10 / 151)$ were positive for $E S \beta L$ resistance genes $\left(b_{l} a_{C T X-M-65}\right) .{ }^{\mathrm{d}} \mathrm{S}$ : Susceptible and R: Resistance. ${ }^{\mathrm{e}}$ Antimicrobial resistance and virulence analyses were performed using CARD and VFDB. ${ }^{\mathrm{f}}$ All isolates belonged to serovar Infantis and contained the gols gene, not shown.

\section{Discussion}

This is the first documented WGS study conducted in the poultry (broilers and layers) industry along the broiler production chain in Trinidad and Tobago, and the Caribbean 
region at large. Whole-genome sequencing analysis has been used to investigate genetic characteristics and phylogenies among Salmonella strains isolated from different origins, such as humans, food, animals, and the environment [33-36]. The current study was comprised of isolates from four cross-sectional studies conducted at the level of retail outlets (2016-2017) [25], broiler processing plants (2018) [23], broiler farms, and broiler hatcheries (2019) [22]. Although several limitations exist with the use of cross-sectional instead of longitudinal studies, this approach provides valuable information on the status of Salmonella shedding and contamination at the four levels (hatcheries, farms, processing plants, and retail outlets) of the broiler production chain in the country. Furthermore, the information obtained will lead to a better understanding of the epidemiology of Salmonella and the associated public health implications. Finally, this approach will also facilitate the implementation of an effective surveillance system across the poultry production system in the country.

Using the SISTR pipeline, a 76\% agreement was detected with the traditional conventional serotyping method, which utilizes the White-Kauffman-Le Minor (WKL) scheme, which is based on immunological reactions to somatic $(\mathrm{O})$ and flagellar $(\mathrm{H})$ antigens [37]. However, it has been documented that conventional serotyping is time-consuming, laborintensive, costly, and some isolates do not express serotype antigens due to a single nucleotide change in the genome $[38,39]$. On the other hand, the SISTR pipeline has been validated and a $94.6 \%$ overall serovar prediction accuracy was reported when 4291 genomes were analyzed [29]. In silico serotyping channels such as SISTR provide us with an understanding of the antigenic genes carried by an isolate and not necessarily what is expressed by that isolate, an advantage over traditional serotyping methods. In a study that compared three in silico pipelines, SISTR, SeqSero, and MLST to traditional serotyping techniques using a set of 813 verified clinical and laboratory isolates, $94.8 \%, 88.2 \%$, and $88.3 \%$ accuracy, respectively was reported [40]. Of significance in our study was the incorrect serotype classification by the conventional method of potential public health important serotypes such as S. Albany, Senftenberg, Infantis, and Caracas. Variations in Salmonella serovars in poultry have been reported in different countries and are known to be a function of geographic location [5]. In Egypt [41], serovars Enteritidis and Typhimurium were isolated from broiler chickens at retail outlets; in Japan [42], serovars Infantis, Manhattan, Schwarzengrund from cecal samples in broilers; in China [43], serovars Pullorum, Gallinarum, Enteritidis, and Typhimurium were the predominant serotypes. Unlike our study where $S$. Kentucky, Javiana, Infantis, and Albany were the predominant serovars isolated along the broiler production chain.

Gene $b l a_{\mathrm{CTX}} \mathrm{M}-65$ was detected in $77 \%(31 / 40)$ of the $S$. Infantis strains isolated at Colombian processing plants [44], a finding comparable to the $50 \%(10 / 20)$ detected in the current study. Worldwide, the rapid development of resistance to extended-spectrum cephalosporins, predominantly associated with the production of $\beta$-lactamase-producing bacteria (Es $\beta \mathrm{L}$ ) in different Salmonella serovars, has been reported. In agreement with our study, Es $\beta \mathrm{L}$ resistance genes have been detected in Salmonella strains isolated from animal products in several countries, including Korea (food animals and humans), 1.6\% [45], Mexico (humans and animals), 6.6\% [46], and Brazil (broiler chickens), where 27.8\% [47] of isolates were positive for the $b a_{C T X-M}$ gene. The detection of $6.8 \%$ MDR strains among serovar Infantis isolates possessing the $b l a_{C T X-M-65}$ gene is of public health significance due to the reported cross-transmission of Es $\beta$ L-producing bacterial strains from poultry farms to other livestock farms and humans with the potential for wide-spread population infections [48,49]. A cause for concern is the detection of 10 MDR serovar Infantis strains, each possessing the $b l a_{C T X-M-65}$ gene, in addition to 38 virulence homologs according to VFDB. In 2014, the detection of an MDR emergent Salmonella Infantis (ESI) strain, often containing the $b a_{C T X-M-65}$ gene, was first reported in Israel, and subsequently detected in Italy, Japan, and Russia [50-53]. However, retrospective sequencing tracked the origins of this clone to South America [54,55]. This ESI strain was documented to carry a large plasmid ESI (pESI) with several antimicrobial resistance, metal, and virulence genes. This 
clone was detected in retail meats in Tennessee, USA, in 2014, but by 2019 had spread throughout the USA to comprise $29 \%$ Salmonella isolated from retail chickens and $7 \%$ from retail turkey [56]. This clone also accounted for nearly $10 \%$ of all human Infantis cases by 2017 in the United States and was highly related to chicken sources [57]. The most frequently described ES $\beta$ L genotype in Colombia between 1997-2018 was CTX-M, which was detected primarily in S. Typhimurium (40\%; 65/164) and S. Infantis (29\%; 48/164). Detection of $b l a_{C T X}$ genes has been reported in Latin American countries, such as Brazil and Argentina [58]. The assumption was that cephalosporin resistance development was due to the injection of ceftiofur into fertile eggs at hatcheries to prevent $E$. coli-induced omphalitis in day-old chicks [59]. This assumption was supported by a Canadian study that revealed a strong correlation between this practice and the increase in ceftiofur-resistant strains of $S$. Heidelberg [60]. This practice was not evident at hatcheries in our study, nor were bla genes detected among hatchery isolates.

A quick look into the NCBI Pathogen detection browser (https://www.ncbi.nlm. nih.gov / pathogens) allows us to determine that the eight strains of $S$. Infantis (ST32) detected in this study were highly related to the MDR emergent $S$. Infantis strains carrying

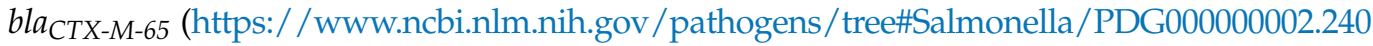
5/PDS000089910.160?term=CFSAN103822,\%20CFSAN103806,\%20CFSAN103805,\%20CFSAN1 03797,\%20CFSAN103801,\%20CFSAN103796,\%20CFSAN103798,\%20CFSAN103802, accessed on 2 March 2022) reported in previous studies [50-57]. This highlights the usefulness of WGS approaches for AMR surveillance in a country or region, in this case, Trinidad and Tobago, considering the significant public health and clinical implications resulting from the presence of this large plasmid ESI. The plasmid detected in our $S$. Infantis carrying the CTX-M-65 gene (Accession: CP066336.1) contained 312,952 bp, differing from the plasmids reported in the USA [61] and Italy [52], which ranged from 316,160 to 323,122bp. These eight strains exhibited two resistance profiles: aac(3)-IVa, aadA1, aph(3')-Ia, aph(4)-Ia, bla $C T X-M-65, d f r A 14$, gyr $A \_D 87 Y, m d s A, m d s B, \operatorname{sul1}$, tet( $\left.A\right)$ (4 strains) and aac(3)-IVa, aadA1, aph(4)-Ia, bla $a_{C T X-M-65}, d f r A 14, g y r A \_D 87 Y, m d s A, m d s B$, sul1, tet $(A)$ (4 strains), according to the NCBI database (AMRFinderPlus). Our findings were similar to the aph(4)-Ia, aac(3)-IVa, aph (3')-Ic, bla CTX-M-65, fosA3, floR, dfrA14, gyrA_D87Y, sul1, tet A, aadA1 pattern detected in the USA [61] and aph(4)-Ia, aac(3)-IVa, aph(3')-Ic, bla CTX-M-65, fosA3, floR, dfrA14, sul1, tet A, aadA1 detected clinically in Italy [52], where both studies used ResFinder.

It must be highlighted that Es $\beta$ L-producing K. pneumoniae was detected in $78.8 \%$ $(41 / 52)$ of clinical isolates originating from a tertiary care hospital in Trinidad and Tobago, where the $b l a_{S H V}$ and $b l a_{C T X-M}$ genes were predominantly detected [62]. It is of interest that all the MDR Infantis strains isolated in the current study originated from broiler farms. This is because there is a potential for Salmonella strains positive for bla $a_{C T X}$ gene, AMR, and associated virulence genes, to enter the human food chain through the processing plants and chicken products at the retail outlets. This is supported by reports documenting close association of MDR Infantis strains recovered from the broiler population to animal production environments, eventually spreading into the food chain and potentially humans $[63,64]$.

As with this study, aminoglycoside resistance genes and sul1 genes were also detected in Salmonella Infantis strains isolated in a recent study conducted at three Colombian broiler processing plants [44]. Sulphonamide resistance conferred by sul genes [65] was reported in Canadian swine and chicken Salmonella isolates [66] and at a broiler processing plant in China [67]. However, in our study, only the sul1 gene was detected in all our S. Infantis strains and the only Senftenberg strain assessed. Arkali et al. [68] detected the sul1 gene among $58 \%$ of Salmonella isolated from chickens in Eastern Turkey. The detection of one mobilized colistin resistance $m c r-9.1$ gene [69] in an isolate of serovar Senftenberg was not a significant finding. This gene is not associated with colistin resistance in Salmonella or E. coli in the United States [70]. However, detecting this novel mcr-9 homolog is crucial as it can confer phenotypic resistance to colistin and warrants close monitoring [16].

The qacEdelta1 gene, known to confer resistance to antiseptics, was also detected in Salmonella from retail foods of animal origin [20]. It must be considered that the presence 
of antimicrobial resistance genes can represent the phenotypic resistance of antimicrobial agents, and thus diminish their effectiveness when used on farms or processing plants. However, it is important to mention that there are several mechanisms of antimicrobial resistance in bacteria. It is not always associated with a specific gene responsible for resistance. This supports our findings where resistance genes were found in two Infantis strains, but they were all sensitive phenotypically. Cross-resistance to antimicrobial agents can occur with resistance within group members of chemical-related compounds, and/or with a similar mechanism of action [71,72]. The correlation of genotypic and phenotypic resistance was variable in our study, contrary to the findings of other studies where the harmonic correlation was evident $[67,73]$. The lack of correlation between phenotypic and genotypic resistance profiles may occur due to the low sensitivity and specificity of the disk method, inoculum concentration, laboratory capacity, and individual skill. Misalignments between phenotypic and genotypic resistance patterns have been reported by others $[74,75]$.

In the current study, only $6.8 \%(10 / 146)$ of the isolates, based on genotypic characterization, exhibited multidrug resistance, at variance with the $96.6 \%$ reported in Salmonella isolated from chickens sampled at chicken farms in South Africa [76] and the 27.3\% reported for Salmonella strains isolated from broilers in Egypt [77]. Therefore, our low frequency of detecting MDR is of therapeutic significance at the broiler farm level in the country.

SPI-1 and SPI-2 genes enable the invasion of eukaryotic cells, induction of macrophage cytotoxicity, invasion of phagocytes, and survival inside phagocytic cells [78-81]. The inactivation of the TTSS-1 translocated effector gene sipB in S. Dublin has been associated with reduced fluid secretion and inflammation [82]. This is of public health significance because of the 73 genes detected in the current study, 49.3\% and 35.6\% were detected in Salmonella strains isolated from processing plants and retail outlets, respectively, highlighting the risk posed to consumers should they be infected with a serovar positive for the gene. In the current study, serovars Aberdeen, Anatum, Enteritidis, Infantis, Javiana, Manhattan, Virchow, and Weltevreden were all positive for the $\operatorname{sip} B$ gene.

Fimbrial adherence factors that aid intestinal adhesion such as long polar fimbriae $(\operatorname{lpf} A)$ and aggregative fimbriae $(\operatorname{ag} f A / \operatorname{csg} A)$ are highly conserved in Salmonella and have been implicated in biofilm formation and adhesion to surfaces and epithelial cells that is an important stage before biofilm formation, respectively [83,84]. This is important in the current study because $99.3 \%$ of the isolates were positive for the $\operatorname{cs} g A$ gene, therefore having the potential for biofilm formation and persistence in the environment. In addition, the high incidence of $\operatorname{csg} A$ in our study is comparable to the findings in different serovars, as reported by others $[85,86]$.

Typhoid toxin $/ c d t B$ cytolethal distending toxin B, previously thought to be a unique virulence factor in $S$. Typhi, was recently characterized in at least 40 non-typhoidal Salmonella serovars [87], as evident in our study. The detection of virulence genes $\operatorname{inv} A, \operatorname{csg} A, \operatorname{lpf} A$, $s o p E$, and $s p v C$ in our $S$. Enteritidis strains agrees with the findings of studies conducted on chickens sold at Bangladeshi retail outlets [88], in food and humans in Brazil [89], and in humans and animals in Iran [90].

The positive correlations in the detection of AMR and virulence genes in the Salmonella serovars isolated from farms, retail outlets, and 'pluck shops' are indicative of close similarities in the occurrence of AMR and virulence genes in different serovars and isolates in the study area or source-dependent AMR/virulence profiles. The presence of virulence genes and the occurrence of AMR Salmonella isolates can potentially accelerate the pathogenicity of microbes [91]. It has also been reported that the emergence of resistant Salmonella enterica solely depends on genetic and pathogenicity mechanisms that may enhance survivability by preserving their drug resistance genes [92]. However, the correlation between AMR and virulence has been shown to vary in studies conducted by others. The acquisition of AMR by Salmonella isolates decreases [93,94], increases [95,96], or does not change [97,98] their potential virulence according to those authors. 


\section{Conclusions}

This study highlighted the antimicrobial resistance and virulence genes associated with Salmonella serovars isolated along the broiler production chain in Trinidad and Tobago. The detection of the bla $a_{C T X-M-65}$ gene, MDR, and highly virulent $S$. Infantis isolates based on their genotypes, is cause for concern given their international emergence and implications for human health. The positive correlation of resistance and virulence genes detected at broiler farms, processing plants, and retail outlets ('pluck shops') is significant since the latter two stages of the broiler continuum can directly impact consumers of contaminated, improperly handled, or cooked chicken.

The availability of these genomes will help future source tracking during epidemiological investigations associated with Salmonella foodborne outbreaks in the region and worldwide. Therefore, the abundance of data from several sources in the country will benefit the scientific community at large.

Supplementary Materials: The following are available online at https:/ /www.mdpi.com/article/ 10.3390/microorganisms10030570/s1, Table S1: Metadata of 146 Salmonella isolates detected along the broiler production chain in Trinidad and Tobago. Table S2: Distribution of virulence genes and classes among the various serovars of Salmonella isolated in this study.

Author Contributions: Conceptualization, A.A.A., A.S.K. and K.G.; methodology, A.A.A., A.S.K., R.E.P., N.G.-E., M.M., C.L., G.H.T. and S.A.; software, R.E.P., N.G.-E., M.M. and G.H.T.; validation, R.E.P., N.G.-E., M.M. and G.H.T.; formal analysis, R.E.P., A.A.A. and A.S.K.; investigation, A.A.A., A.S.K. and K.G.; resources, A.A.A., N.G.-E., M.M., G.H.T. and S.A.; data curation, A.A.A., A.S.K. and R.E.P.; writing—original draft preparation, A.A.A., A.S.K. and W.A.; writing—review and editing, A.A.A., A.S.K., K.G., R.E.P., N.G.-E., M.M., C.L., G.H.T. and S.A.; visualization, R.E.P., A.S.K. and A.A.A.; supervision, A.A.A., K.G. and W.A.; project administration, A.A.A., A.S.K. and K.G.; funding acquisition, A.A.A. and A.S.K. All authors have read and agreed to the published version of the manuscript.

Funding: The University of the West Indies, St. Augustine Campus Research and Publication Fund Committee approved the funding for the project (Research grant \#2660-457522 on 3 July 2017).

Institutional Review Board Statement: The study was approved and conducted under terms approved by the University of the West Indies, St. Augustine Campus Research Committee (Research grant \#2660-457522 on 13 April 2016). The UWI St. Augustine Campus Ethics Committee exempted the project from ethical review after assessing the research proposal.

Informed Consent Statement: Written informed consent has been obtained from the patient(s) by the Caribbean Public Health Agency (CARPHA) from where the five isolates of Salmonella originated, to publish this paper.

Data Availability Statement: All the data are contained within the article and the Supplementary Materials.

Acknowledgments: We thank the staff of the Public Health Agency of Canada (PHAC) Laboratory for conducting some whole-genome sequencing. We are grateful to the staff of the Bacteriology section of the Caribbean Public Health Agency (CARPHA), Port-of-Spain for providing strains of Salmonella Infantis and Enteritidis isolated from human gastroenteritis cases in the country. The technical assistance of Alva Marie Stewart-Johnson and Sannandan Samlal is appreciated.

Conflicts of Interest: The authors declare no conflict of interest. The funders had no role in the design of the study; in the collection, analysis, or interpretation of data; in the writing of the manuscript, or in the decision to publish the results. The views expressed in this article are those of the authors and do not necessarily reflect the official policy of the Department of Health and Human Services, the U.S. Food and Drug Administration, or the U.S. Government.

\section{References}

1. Ulaya, D.W. Determination of virulence factors in Salmonella isolates of human, poultry, and dog origin in Lusaka district, Zambia. Master's Thesis, University of Zambia, Lusaka, Zambia, 2014. 
2. Centers for Disease Control and Prevention. Salmonella. Available online: https://www.cdc.gov/salmonella/index.html (accessed on 3 October 2020).

3. European Food Safety Authority; European Centre for Disease Prevention Control. The European Union One Health 2018 zoonoses report. EFSA J. 2019, 17, e05926. [CrossRef]

4. Shilangale, R.P.; Di Giannatale, E.; Chimwamurombe, P.M.; Kaaya, G.P. Prevalence and antimicrobial resistance pattern of Salmonella in animal feed produced in Namibia. Vet. Ital. 2012, 48, 125-132. [PubMed]

5. Foley, S.L.; Lynne, A.M.; Nayak, R. Salmonella challenges: Prevalence in swine and poultry and potential pathogenicity of such isolates. J. Anim. Sci. 2008, 86, E149-E162. [CrossRef] [PubMed]

6. Kimera, Z.I.; Mshana, S.E.; Rweyemamu, M.M.; Mboera, L.E.G.; Matee, M.I.N. Antimicrobial use and resistance in food-producing animals and the environment: An African perspective. Antimicrob. Resist. Infect. Control. 2020, 9, 37. [CrossRef] [PubMed]

7. Ma, F.; Xu, S.; Tang, Z.; Li, Z.; Zhang, L. Use of antimicrobials in food animals and impact of transmission of antimicrobial resistance on humans. Biosaf. Health 2021, 3, 32-38. [CrossRef]

8. World Health Organization (WHO). Critically Important Antimicrobials for Human Medicine; World Health Organisation: Geneva, Switzerland, 2019.

9. Collignon, P.J.; Conly, J.M.; Andremont, A.; McEwen, S.A.; Aidara-Kane, A.; Agerso, Y.; Andremont, A.; Collignon, P.; Conly, J.; Dang Ninh, T.; et al. World Health Organization ranking of antimicrobials according to their importance in human medicine: A critical step for developing risk management strategies to control antimicrobial resistance from food animal production. Clin. Infect. Dis. 2016, 63, 1087-1093. [CrossRef] [PubMed]

10. Wang, M.; Sahm, D.F.; Jacoby, G.A.; Hooper, D.C. Emerging plasmid-mediated quinolone resistance associated with the qnr gene in Klebsiella pneumoniae clinical isolates in the United States. Antimicrob. Agents Chemother. 2004, 48, 1295-1299. [CrossRef]

11. Hooper, D.C.; Jacoby, G.A. Mechanisms of drug resistance: Quinolone resistance. Ann. NY Acad. Sci. 2015, 1354, 12-31. [CrossRef]

12. Fàbrega, A.; Madurga, S.; Giralt, E.; Vila, J. Mechanism of action of and resistance to quinolones. Microb. Biotechnol. 2009, 2, 40-61. [CrossRef]

13. Chen, S.; Zhao, S.; White, D.G.; Schroeder, C.M.; Lu, R.; Yang, H.; McDermott, P.F.; Ayers, S.; Meng, J. Characterization of multiple-antimicrobial-resistant Salmonella serovars isolated from retail meats. Appl. Environ. Microbiol. 2004, 70, 1-7. [CrossRef]

14. Miko, A.; Pries, K.; Schroeter, A.; Helmuth, R. Molecular mechanisms of resistance in multidrug-resistant serovars of Salmonella enterica isolated from foods in Germany. J. Antimicrob. Chemother. 2005, 56, 1025-1033. [CrossRef] [PubMed]

15. Liu, Y.Y.; Wang, Y.; Walsh, T.R.; Yi, L.X.; Zhang, R.; Spencer, J.; Doi, Y.; Tian, G.; Dong, B.; Huang, X.; et al. Emergence of plasmid-mediated colistin resistance mechanism mor-1 in animals and human beings in China: A microbiological and molecular biological study. Lancet Infect. Dis. 2016, 16, 161-168. [CrossRef]

16. Carroll, L.M.; Gaballa, A.; Guldimann, C.; Sullivan, G.; Henderson, L.O.; Wiedmann, M. Identification of novel mobilized colistin resistance gene $m c r-9$ in a multidrug-resistant, colistin-susceptible Salmonella enterica serotype Typhimurium isolate. $m B i o$ 2019, 10, e00853-19. [CrossRef] [PubMed]

17. Borowiak, M.; Baumann, B.; Fischer, J.; Thomas, K.; Deneke, C.; Hammerl, J.A.; Szabo, I.; Malorny, B. Development of a novel mcr-6 to mcr-9 multiplex PCR and assessment of mcr-1 to mcr-9 occurrence in colistin-resistant Salmonella enterica isolates from environment, feed, animals and food (2011-2018) in Germany. Front. Microbiol. 2020, 11, 80. [CrossRef]

18. Rebelo, A.R.; Bortolaia, V.; Kjeldgaard, J.S.; Pedersen, S.K.; Leekitcharoenphon, P.; Hansen, I.M.; Guerra, B.; Malorny, B.; Borowiak, M.; Hammerl, J.A.; et al. Multiplex PCR for detection of plasmid-mediated colistin resistance determinants, $m c r-1$, $m c r-2, m c r-3, m c r-4$, and $m c r-5$ for surveillance purposes. Eurosurveillance 2018, 23, 17-00672. [CrossRef]

19. Eguale, T.; Birungi, J.; Asrat, D.; Njahira, M.N.; Njuguna, J.; Gebreyes, W.A.; Gunn, J.S.; Djikeng, A.; Engidawork, E. Genetic markers associated with resistance to beta-lactam and quinolone antimicrobials in non-typhoidal Salmonella isolates from humans and animals in central Ethiopia. Antimicrob. Resist. Infect. Control. 2017, 6, 13. [CrossRef]

20. Deng, W.; Quan, Y.; Yang, S.; Guo, L.; Zhang, X.; Liu, S.; Chen, S.; Zhou, K.; He, L.; Li, B.; et al. Antibiotic resistance in Salmonella from retail foods of animal origin and its association with disinfectant and heavy metal resistance. Microb. Drug Resist. 2018, 24, 782-791. [CrossRef]

21. Vilela, F.P.; Gomes, C.N.; Passaglia, J.; Rodrigues, D.P.; Costa, R.G.; Tiba Casas, M.R.; Fernandes, S.A.; Falcão, J.P.; Campioni, F. Genotypic resistance to quinolone and tetracycline in Salmonella Dublin strains isolated from humans and animals in Brazil. Microb. Drug Resist. 2019, 25, 143-151. [CrossRef]

22. Khan, A.S.; Georges, K.; Rahaman, S.; Abebe, W.; Adesiyun, A.A. Occurrence, risk factors, serotypes and antimicrobial resistance of Salmonella strains isolated from imported fertile hatching eggs, hatcheries, and broiler farms in Trinidad and Tobago. J. Food Prot. 2021, 85, 266-277. [CrossRef]

23. Khan, A.S.; Georges, K.; Rahaman, S.; Abebe, W.; Adesiyun, A.A. Characterization of Salmonella isolates recovered from stages of the processing lines at four broiler processing plants in Trinidad and Tobago. Microorganisms 2021, 9, 1048. [CrossRef]

24. Khan, A.S.; Georges, K.; Rahaman, S.; Abdela, W.; Adesiyun, A.A. Antimicrobial resistance of Salmonella isolates recovered from chickens sold at retail outlets in Trinidad. J. Food Prot. 2018, 81, 1880-1889. [CrossRef] [PubMed]

25. Khan, A.S.; Georges, K.; Rahaman, S.; Abdela, W.; Adesiyun, A.A. Prevalence and serotypes of Salmonella spp. on chickens sold at retail outlets in Trinidad. PLoS ONE 2018, 13, e0202108. [CrossRef] [PubMed]

26. Rodrigo, S.; Adesiyun, A.A.; Asgarali, Z.; Swanston, W. Occurrence of selected foodborne pathogens on poultry and poultry giblets from small retail processing operations in Trinidad. J. Food Prot. 2006, 69, 1096-1105. [CrossRef] [PubMed] 
27. Andrews, W. Manual of food quality control. 4. Rev. 1. Microbiological analysis. Food and Drug Administration. FAO Food Nutr. Pap. 1992, 14, 1-338.

28. Bankevich, A.; Nurk, S.; Antipov, D.; Gurevich, A.A.; Dvorkin, M.; Kulikov, A.S.; Lesin, V.M.; Nikolenko, S.I.; Pham, S.; Prjibelski, A.D.; et al. SPAdes: A new genome assembly algorithm and its applications to single-cell sequencing. J. Comput. Biol. 2012, 19, 455-477. [CrossRef]

29. Yoshida, C.E.; Kruczkiewicz, P.; Laing, C.R.; Lingohr, E.J.; Gannon, V.P.; Nash, J.H.; Taboada, E.N. The Salmonella in silico typing resource (SISTR): An open web-accessible tool for rapidly typing and subtyping draft Salmonella genome assemblies. PLoS ONE 2016, 11, e0147101. [CrossRef]

30. Hyatt, D.; Chen, G.L.; Locascio, P.F.; Land, M.L.; Larimer, F.W.; Hauser, L.J. Prodigal: Prokaryotic gene recognition and translation initiation site identification. BMC Bioinform. 2010, 11, 119. [CrossRef]

31. Liu, B.; Zheng, D.; Jin, Q.; Chen, L.; Yang, J. VFDB 2019: A comparative pathogenomic platform with an interactive web interface Nucleic Acids Res. 2019, 47, D687-D692. [CrossRef]

32. Alcock, B.P.; Raphenya, A.R.; Lau, T.T.Y.; Tsang, K.K.; Bouchard, M.; Edalatmand, A.; Huynh, W.; Nguyen, A.V.; Cheng, A.A.; Liu, S.; et al. CARD 2020: Antibiotic resistome surveillance with the comprehensive antibiotic resistance database. Nucleic. Acids Res. 2020, 48, D517-D525. [CrossRef]

33. Lee, D.H.; Hyeon, J.Y.; Kim, J.; Kim, J.S.; Kim, S.J.; Jeon, S.E.; Choi, S.W.; Hong, W.T.; Song, C.S.; Lee, S.W. Close genetic relationship between Salmonella enterica serovar Enteritidis isolated from patients with diarrhoea and poultry in the Republic of Korea. Clin. Microbiol. Infect. 2015, 21, e68-e70. [CrossRef]

34. Almeida, F.; Medeiros, M.I.; Kich, J.D.; Falcao, J.P. Virulence-associated genes, antimicrobial resistance and molecular typing of Salmonella Typhimurium strains isolated from swine from 2000 to 2012 in Brazil. J. Appl. Microbiol. 2016, 120, 1677-1690. [CrossRef] [PubMed]

35. Pearce, M.E.; Alikhan, N.F.; Dallman, T.J.; Zhou, Z.; Grant, K.; Maiden, M.C.J. Comparative analysis of core genome MLST and SNP typing within a European Salmonella serovar Enteritidis outbreak. Int. J. Food. Microbiol. 2018, 274, 1-11. [CrossRef] [PubMed]

36. Pightling, A.W.; Pettengill, J.B.; Luo, Y.; Baugher, J.D.; Rand, H.; Strain, E. Interpreting whole-genome sequence analyses of foodborne bacteria for regulatory applications and outbreak investigations. Front. Microbiol. 2018, 9, 1482. [CrossRef] [PubMed]

37. Guibourdenche, M.; Roggentin, P.; Mikoleit, M.; Fields, P.I.; Bockemuhl, J.; Grimont, P.A.; Weill, F.X. Supplement $2003-2007$ (No 47) to the White-Kauffmann-Le Minor scheme. Res. Microbiol. 2010, 161, 26-29. [CrossRef]

38. Li, P.; Liu, Q.; Luo, H.; Liang, K.; Yi, J.; Luo, Y.; Hu, Y.; Han, Y.; Kong, Q. O-serotype conversion in Salmonella Typhimurium induces protective immune responses against invasive non-typhoidal Salmonella infections. Front. Immunol. 2017, 8, 1647. [CrossRef]

39. Chui, L.; Ferrato, C.; Li, V.; Christianson, S. Comparison of molecular and in silico Salmonella serotyping for Salmonella surveillance. Microorganisms 2021, 9, 955. [CrossRef]

40. Yachison, C.A.; Yoshida, C.; Robertson, J.; Nash, J.H.E.; Kruczkiewicz, P.; Taboada, E.N.; Walker, M.; Reimer, A.; Christianson, S.; Nichani, A.; et al. The validation and implications of using whole-genome sequencing as a replacement for traditional serotyping for a National Salmonella reference laboratory. Front. Microbiol. 2017, 8, 1044. [CrossRef]

41. Elkenany, R.; Elsayed, M.M.; Zakaria, A.I.; El-sayed, S.A.-E.-S.; Rizk, M.A. Antimicrobial resistance profiles and virulence genotyping of Salmonella enterica serovars recovered from broiler chickens and chicken carcasses in Egypt. BMC Vet. Res. 2019, 15, 124. [CrossRef]

42. Duc, V.M.; Nakamoto, Y.; Fujiwara, A.; Toyofuku, H.; Obi, T.; Chuma, T. Prevalence of Salmonella in broiler chickens in Kagoshima, Japan in 2009 to 2012 and the relationship between serovars changing and antimicrobial resistance. BMC Vet. Res. 2019, 15, 108. [CrossRef]

43. Wang, X.; Wang, H.; Li, T.; Liu, F.; Cheng, Y.; Guo, X.; Wen, G.; Luo, Q.; Shao, H.; Pan, Z.; et al. Characterization of Salmonella spp. isolated from chickens in Central China. BMC Vet. Res. 2020, 16, 299. [CrossRef]

44. Ramirez-Hernandez, A.; Carrascal-Camacho, A.K.; Varon-Garcia, A.; Brashears, M.M.; Sanchez-Plata, M.X. Genotypic characterization of antimicrobial resistant Salmonella spp. strains from three poultry processing plants in Colombia. Foods 2021, 10, 491. [CrossRef] [PubMed]

45. Tamang, M.D.; Nam, H.M.; Kim, T.S.; Jang, G.C.; Jung, S.C.; Lim, S.K. Emergence of extended-spectrum beta-lactamase (CTX-M-15 and CTX-M-14)-producing nontyphoid Salmonella with reduced susceptibility to ciprofloxacin among food animals and humans in Korea. J. Clin. Microbiol. 2011, 49, 2671-2675. [CrossRef] [PubMed]

46. Aguilar-Montes de Oca, S.; Talavera-Rojas, M.; Soriano-Vargas, E.; Barba-Leon, J.; Vazquez-Navarrete, J.; Acosta-Dibarrat, J.; Salgado-Miranda, C. Phenotypic and genotypic profile of clinical and animal multidrug-resistant Salmonella enterica isolates from Mexico. J. Appl. Microbiol. 2018, 124, 67-74. [CrossRef] [PubMed]

47. Mendonça, E.P.; Melo, R.T.; Oliveira, M.R.M.; Monteiro, G.P.; Peres, P.A.B.M.; Fonseca, B.B.; Giombelli, A.; Rossi, D.A. Characteristics of virulence, resistance and genetic diversity of strains of Salmonella Infantis isolated from broiler chicken in Brazil. Braz. Vet. Res. 2020, 40, 29-38. [CrossRef]

48. Brinas, L.; Moreno, M.A.; Zarazaga, M.; Porrero, C.; Saenz, Y.; Garcia, M.; Dominguez, L.; Torres, C. Detection of CMY-2, CTX-M14, and SHV-12 beta-lactamases in Escherichia coli fecal-sample isolates from healthy chickens. Antimicrob. Agents Chemother. 2003, 47, 2056-2058. [CrossRef] 
49. Winokur, P.L.; Brueggemann, A.; DeSalvo, D.L.; Hoffmann, L.; Apley, M.D.; Uhlenhopp, E.K.; Pfaller, M.A.; Doern, G.V. Animal and human multidrug-resistant, cephalosporin-resistant Salmonella isolates expressing a plasmid-mediated CMY-2 AmpC beta-lactamase. Antimicrob. Agents Chemother. 2000, 44, 2777-2783. [CrossRef]

50. Aviv, G.; Tsyba, K.; Steck, N.; Salmon-Divon, M.; Cornelius, A.; Rahav, G.; Grassl, G.A.; Gal-Mor, O. A unique megaplasmid contributes to stress tolerance and pathogenicity of an emergent Salmonella enterica serovar Infantis strain. Environ. Microbiol. 2014, 16, 977-994. [CrossRef]

51. Bogomazova, A.N.; Gordeeva, V.D.; Krylova, E.V.; Soltynskaya, I.V.; Davydova, E.E.; Ivanova, O.E.; Komarov, A.A. Mega-plasmid found worldwide confers multiple antimicrobial resistance in Salmonella Infantis of broiler origin in Russia. Int. J. Food Microbiol. 2020, 319, 108497. [CrossRef]

52. Franco, A.; Leekitcharoenphon, P.; Feltrin, F.; Alba, P.; Cordaro, G.; Iurescia, M.; Tolli, R.; D’Incau, M.; Staffolani, M.; Di Giannatale, E.; et al. Emergence of a clonal lineage of multidrug-resistant ES $\beta L$-producing Salmonella Infantis transmitted from broilers and broiler meat to humans in Italy between 2011 and 2014. PLoS ONE 2015, 10, e0144802. [CrossRef]

53. Yokoyama, E.; Ando, N.; Ohta, T.; Kanada, A.; Shiwa, Y.; Ishige, T.; Murakami, K.; Kikuchi, T.; Murakami, S. A novel subpopulation of Salmonella enterica serovar Infantis strains isolated from broiler chicken organs other than the gastrointestinal tract. Vet. Microbiol. 2015, 175, 312-318. [CrossRef]

54. Cartelle Gestal, M.; Zurita, J.; Paz, Y.M.A.; Ortega-Paredes, D.; Alcocer, I. Characterization of a small outbreak of Salmonella enterica serovar Infantis that harbour CTX-M-65 in Ecuador. Braz. J. Infect. Dis. 2016, 20, 406-407. [CrossRef] [PubMed]

55. Palma, N.; Pons, M.J.; Gomes, C.; Mateu, J.; Riveros, M.; Garcia, W.; Jacobs, J.; Garcia, C.; Ochoa, T.J.; Ruiz, J. Resistance to quinolones, cephalosporins and macrolides in Escherichia coli causing bacteraemia in Peruvian children. J. Glob. Antimicrob. Resist. 2017, 11, 28-33. [CrossRef] [PubMed]

56. Tyson, G.H.; Li, C.; Harrison, L.B.; Martin, G.; Hsu, C.H.; Tate, H.; Tran, T.T.; Strain, E.; Zhao, S. A multidrug-resistant Salmonella Infantis clone is spreading and recombining in the United States. Microb. Drug Resist. 2021, 27, 792-799. [CrossRef] [PubMed]

57. Brown, A.C.; Chen, J.C.; Watkins, L.K.F.; Campbell, D.; Folster, J.P.; Tate, H.; Wasilenko, J.; Van Tubbergen, C.; Friedman, C.R. CTX-M-65 extended-spectrum beta-lactamase-producing Salmonella enterica serotype Infantis, United States. Emerg. Infect. Dis. 2018, 24, 2284-2291. [CrossRef] [PubMed]

58. Bonnet, R. Growing group of extended-spectrum beta-lactamases: The CTX-M enzymes. Antimicrob. Agents Chemother. 2004, 48, 1-14. [CrossRef]

59. Hofacre, C.L.; Fricke, J.A.; Inglis, T. Antimicrobial drug use in poultry. In Antimicrobial Therapy in Veterinary Medicine; Giguère, S., Prescott, J.F., Dowling, P.M., Eds.; John Wiley \& Sons: Hoboken, NJ, USA, 2013; pp. 569-587.

60. Dutil, L.; Irwin, R.; Finley, R.; Ng, L.K.; Avery, B.; Boerlin, P.; Bourgault, A.M.; Cole, L.; Daignault, D.; Desruisseau, A.; et al. Ceftiofur resistance in Salmonella enterica serovar Heidelberg from chicken meat and humans, Canada. Emerg. Infect. Dis. 2010, 16, 48-54. [CrossRef]

61. Tate, H.; Folster, J.P.; Hsu, C.H.; Chen, J.; Hoffmann, M.; Li, C.; Morales, C.; Tyson, G.H.; Mukherjee, S.; Brown, A.C.; et al. Comparative analysis of extended-spectrum-beta-lactamase CTX-M-65-producing Salmonella enterica serovar Infantis isolates from humans, food animals, and retail chickens in the United States. Antimicrob. Agents Chemother. 2017, 61, e00488-17. [CrossRef]

62. Cheddie, P.; Dziva, F.; Akpaka, P.E. Detection of a CTX-M group 2 beta-lactamase gene in a Klebsiella pneumoniae isolate from a tertiary care hospital, Trinidad and Tobago. Ann. Clin. Microbiol. Antimicrob. 2017, 16, 33. [CrossRef]

63. Hindermann, D.; Gopinath, G.; Chase, H.; Negrete, F.; Althaus, D.; Zurfluh, K.; Tall, B.D.; Stephan, R.; Nuesch-Inderbinen, M. Salmonella enterica serovar Infantis from food and human infections, Switzerland, 2010-2015: Poultry-related multidrug resistant clones and an emerging ESBL producing clonal lineage. Front. Microbiol. 2017, 8, 1322. [CrossRef]

64. Nógrády, N.; Király, M.; Davies, R.; Nagy, B. Multidrug resistant clones of Salmonella Infantis of broiler origin in Europe. Int. J. Food Microbiol. 2012, 157, 108-112. [CrossRef]

65. Sköld, O. Resistance to trimethoprim and sulfonamides. Vet. Res. 2001, 32, 261-273. [CrossRef] [PubMed]

66. Kozak, G.K.; Pearl, D.L.; Parkman, J.; Reid-Smith, R.J.; Deckert, A.; Boerlin, P. Distribution of sulfonamide resistance genes in Escherichia coli and Salmonella isolates from swine and chickens at abattoirs in Ontario and Quebec, Canada. Appl. Environ. Microbiol. 2009, 75, 5999-6001. [CrossRef] [PubMed]

67. Zhu, Y.; Lai, H.; Zou, L.; Yin, S.; Wang, C.; Han, X.; Xia, X.; Hu, K.; He, L.; Zhou, K.; et al. Antimicrobial resistance and resistance genes in Salmonella strains isolated from broiler chickens along the slaughtering process in China. Int. J. Food Microbiol. 2017, 259, 43-51. [CrossRef] [PubMed]

68. Arkali, A.; Cetinkaya, B. Molecular identification and antibiotic resistance profiling of Salmonella species isolated from chickens in eastern Turkey. BMC Vet. Res. 2020, 16, 205. [CrossRef] [PubMed]

69. Maguire, M.; Khan, A.S.; Adesiyun, A.A.; Georges, K.; Gonzalez-Escalona, N. Closed genome sequence of a Salmonella enterica serotype Senftenberg strain carrying the mcr-9 gene isolated from broken chicken eggshells in Trinidad and Tobago. Microbiol. Resour. Announc. 2021, 10, e0146520. [CrossRef]

70. Tyson, G.H.; Li, C.; Hsu, C.H.; Ayers, S.; Borenstein, S.; Mukherjee, S.; Tran, T.T.; McDermott, P.F.; Zhao, S. The mcr-9 Gene of Salmonella and Escherichia coli is not associated with colistin resistance in the United States. Antimicrob. Agents Chemother. 2020, 64, e00573-20. [CrossRef]

71. Sefton, A.M. Mechanisms of antimicrobial resistance: Their clinical relevance in the new millennium. Drugs 2002, 62, 557-566. [CrossRef] 
72. Sosa, A.d.J.; Byarugaba, D.K.; Amábile-Cuevas, C.F.; Hsueh, P.-R.; Kariuki, S.; Okeke, I.N. Antimicrobial Resistance in Developing Countries; Springer: Berlin, Germany, 2010; pp. 1-554.

73. Alam, S.B.; Mahmud, M.; Akter, R.; Hasan, M.; Sobur, A.; Nazir, K.N.H.; Noreddin, A.; Rahman, T.; El Zowalaty, M.E.; Rahman, M. Molecular detection of multidrug resistant Salmonella species isolated from broiler farm in Bangladesh. Pathogens 2020, 9, 201. [CrossRef]

74. Van, T.T.; Chin, J.; Chapman, T.; Tran, L.T.; Coloe, P.J. Safety of raw meat and shellfish in Vietnam: An analysis of Escherichia coli isolations for antibiotic resistance and virulence genes. Int. J. Food Microbiol. 2008, 124, 217-223. [CrossRef]

75. Paterson, D.L.; Bonomo, R.A. Extended-spectrum beta-lactamases: A clinical update. Clin. Microbiol. Rev. 2005, 18, 657-686. [CrossRef]

76. Akinola, S.A.; Mwanza, M.; Ateba, C.N. Occurrence, genetic diversities and antibiotic resistance profiles of Salmonella serovars isolated from chickens. Infect. Drug Resist. 2019, 12, 3327-3342. [CrossRef] [PubMed]

77. Ammar, A.M.; Abdeen, E.E.; Abo-Shama, U.H.; Fekry, E.; Kotb Elmahallawy, E. Molecular characterization of virulence and antibiotic resistance genes among Salmonella serovars isolated from broilers in Egypt. Lett. Appl. Microbiol. 2019, 68, 188-195. [CrossRef] [PubMed]

78. Kaniga, K.; Trollinger, D.; Galán, J.E. Identification of two targets of the type III protein secretion system encoded by the inv and spa loci of Salmonella Typhimurium that have homology to the Shigella IpaD and IpaA proteins. J. Bacteriol. 1995, 177, 7078-7085. [CrossRef] [PubMed]

79. Chen, L.M.; Kaniga, K.; Galán, J.E. Salmonella spp. are cytotoxic for cultured macrophages. Mol. Microbiol. 1996, 21, 1101-1115. [CrossRef] [PubMed]

80. Hensel, M.; Shea, J.E.; Waterman, S.R.; Mundy, R.; Nikolaus, T.; Banks, G.; Vazquez-Torres, A.; Gleeson, C.; Fang, F.C.; Holden, D.W. Genes encoding putative effector proteins of the type III secretion system of Salmonella pathogenicity island 2 are required for bacterial virulence and proliferation in macrophages. Mol. Microbiol. 1998, 30, 163-174. [CrossRef] [PubMed]

81. Cirillo, D.M.; Valdivia, R.H.; Monack, D.M.; Falkow, S. Macrophage-dependent induction of the Salmonella pathogenicity island 2 type III secretion system and its role in intracellular survival. Mol. Microbiol. 1998, 30, 175-188. [CrossRef] [PubMed]

82. Galyov, E.E.; Wood, M.W.; Rosqvist, R.; Mullan, P.B.; Watson, P.R.; Hedges, S.; Wallis, T.S. A secreted effector protein of Salmonella Dublin is translocated into eukaryotic cells and mediates inflammation and fluid secretion in infected ileal mucosa. Mol. Microbiol. 1997, 25, 903-912. [CrossRef]

83. Gibson, D.L.; White, A.P.; Rajotte, C.M.; Kay, W.W. AgfC and AgfE facilitate extracellular thin aggregative fimbriae synthesis in Salmonella Enteritidis. Microbiology 2007, 153, 1131-1140. [CrossRef]

84. Yoo, A.Y.; Yu, J.E.; Yoo, H.; Lee, T.H.; Lee, W.H.; Oh, J.I.; Kang, H.Y. Role of sigma factor E in regulation of Salmonella Agf expression. Biochem. Biophys. Res. Commun. 2013, 430, 131-136. [CrossRef]

85. Collinson, S.K.; Doig, P.C.; Doran, J.L.; Clouthier, S.; Trust, T.J.; Kay, W.W. Thin, aggregative fimbriae mediate binding of Salmonella Enteritidis to fibronectin. J. Bacteriol. 1993, 175, 12-18. [CrossRef]

86. Borsoi, A.; Santin, E.; Santos, L.R.; Salle, C.T.; Moraes, H.L.; Nascimento, V.P. Inoculation of newly hatched broiler chicks with two Brazilian isolates of Salmonella Heidelberg strains with different virulence gene profiles, antimicrobial resistance, and pulsed field gel electrophoresis patterns to intestinal changes evaluation. Poult. Sci. 2009, 88, 750-758. [CrossRef] [PubMed]

87. Den Bakker, H.C.; Moreno Switt, A.I.; Govoni, G.; Cummings, C.A.; Ranieri, M.L.; Degoricija, L.; Hoelzer, K.; RodriguezRivera, L.D.; Brown, S.; Bolchacova, E.; et al. Genome sequencing reveals diversification of virulence factor content and possible host adaptation in distinct subpopulations of Salmonella enterica. BMC Genomics 2011, 12, 425. [CrossRef] [PubMed]

88. Siddiky, N.A.; Sarker, M.S.; Khan, M.S.R.; Begum, R.; Kabir, M.E.; Karim, M.R.; Rahman, M.T.; Mahmud, A.; Samad, M.A Virulence and antimicrobial resistance profiles of Salmonella enterica serovars isolated from chicken at wet markets in Dhaka, Bangladesh. Microorganisms 2021, 9, 952. [CrossRef] [PubMed]

89. Campioni, F.; Moratto Bergamini, A.M.; Falcão, J.P. Genetic diversity, virulence genes and antimicrobial resistance of Salmonella Enteritidis isolated from food and humans over a 24-year period in Brazil. Food Microbiol. 2012, 32, 254-264. [CrossRef] [PubMed]

90. Amini, K.; Salehi, T.; Nikbakht Brujeni, G.; Ranjbar, R.; Amini, J.; Ashrafganjooei, S. Molecular detection of invA and spv virulence genes in Salmonella Enteritidis isolated from human and animals in Iran. Afr. J. Microbiol. Res. 2010, 4, $2202-2210$.

91. Huehn, S.; La Ragione, R.M.; Anjum, M.; Saunders, M.; Woodward, M.J.; Bunge, C.; Helmuth, R.; Hauser, E.; Guerra, B.; Beutlich, J.; et al. Virulotyping and antimicrobial resistance typing of Salmonella enterica serovars relevant to human health in Europe. Foodborne Pathog. Dis. 2010, 7, 523-535. [CrossRef] [PubMed]

92. Aslam, M.; Checkley, S.; Avery, B.; Chalmers, G.; Bohaychuk, V.; Gensler, G.; Reid-Smith, R.; Boerlin, P. Phenotypic and genetic characterization of antimicrobial resistance in Salmonella serovars isolated from retail meats in Alberta, Canada. Food Microbiol. 2012, 32, 110-117. [CrossRef] [PubMed]

93. O’Regan, E.; Quinn, T.; Frye, J.G.; Pages, J.M.; Porwollik, S.; Fedorka-Cray, P.J.; McClelland, M.; Fanning, S. Fitness costs and stability of a high-level ciprofloxacin resistance phenotype in Salmonella enterica serotype Enteritidis: Reduced infectivity associated with decreased expression of Salmonella pathogenicity island 1 genes. Antimicrob. Agents Chemother. 2010, 54, 367-374. [CrossRef]

94. Gunn, J.S.; Ryan, S.S.; Van Velkinburgh, J.C.; Ernst, R.K.; Miller, S.I. Genetic and functional analysis of a PmrA-PmrB-regulated locus necessary for lipopolysaccharide modification, antimicrobial peptide resistance, and oral virulence of Salmonella enterica serovar Typhimurium. Infect. Immun. 2000, 68, 6139-6146. [CrossRef] 
95. Tamayo, R.; Ryan, S.S.; McCoy, A.J.; Gunn, J.S. Identification and genetic characterization of PmrA-regulated genes and genes involved in polymyxin B resistance in Salmonella enterica serovar Typhimurium. Infect. Immun. 2002, 70, 6770-6778. [CrossRef]

96. Eswarappa, S.M.; Panguluri, K.K.; Hensel, M.; Chakravortty, D. The yejABEF operon of Salmonella confers resistance to antimicrobial peptides and contributes to its virulence. Microbiology 2008, 154, 666-678. [CrossRef] [PubMed]

97. Nilsson, A.I.; Zorzet, A.; Kanth, A.; Dahlström, S.; Berg, O.G.; Andersson, D.I. Reducing the fitness cost of antibiotic resistance by amplification of initiator tRNA genes. Proc. Natl. Acad. Sci. USA 2006, 103, 6976-6981. [CrossRef] [PubMed]

98. Andersson, D.I.; Hughes, D. Antibiotic resistance and its cost: Is it possible to reverse resistance? Nat. Rev. Microbiol. 2010, 8 , 260-271. [CrossRef] [PubMed] 